\title{
Scenario methods in planning and determining sustainable development of municipalities with Natura 2000 protected areas ${ }^{1}$
}

\author{
Wykorzystanie metod scenariuszowych w planowaniu \\ kierunków rozwoju gmin na obszarach Natura 2000
}

\begin{abstract}
* Dr inż. Waldemar Chmielewski, mgr Magdalena Głogowska, Institute of $\quad$ ** Dr Krzysztof Wrana, University of Economics in Katowice, 1 Maja 50 St., Environmental Protection - National Research Institute, Krucza 5/11d St., 40-287 Katowice, Poland, e-mail: krzysztof wrana@o2.pl

00-548 Warsaw, Poland, e-mail: waldemar.chmielewski@ios.edu.pl,

magda.glogowska@ios.edu.pl
\end{abstract}

Keywords: Sustainable development, Natura 2000, scenario methods, strategic planning

Słowa kluczowe: Zrównoważony rozwój, Natura 2000, metody scenariuszowe, planowanie strategiczne

\section{Abstract}

The purpose of this paper is to analyse the usefulness of applying scenario methods in shaping the processes of development in municipalities, in which special determinants for development are related to the occurrence of especially significant natural values, i.e. municipalities with the Natura 2000 protected areas. The article presents the methodology and scenarios of economic activities development in municipalities located in Natura 2000 protected areas.

\section{Streszczenie}

Celem niniejszego artykułu jest analiza przydatności metod scenariuszowych w procesie kształtowania kierunków rozwoju gmin, w których czynnikami determinującymi są szczegóne walory przyrodnicze, np. gmin położonych na obszarach Natura 2000. Opracowanie prezentuje metodologię budowania scenariuszy rozwoju oraz przykłady scenariuszy rozwojowych gmin z obszarami Natura 2000.

(C) IOŚ-PIB

\section{INTRODUCTION}

The scenario approach is one of the most widespread strategic management methods. This refers both to methods applied in business (Gausemeier et al 1998, Grzegorzewska, Runowski 2008) and in local government (Palang et al 2000, Etienne et al 2003). Simultaneously, their evolution can be seen as well as searching for new applications for them. Making use of the scenario approach is becoming more and more popular for shaping sustainable development of municipalities (Street 1997, Camagni 1992, Kok et al 2006, Brown 2002). Amongst the most important arguments for using the scenario methods at the local level, the following should be mentioned:

- orienting the performed analyses towards the future and conducting strategic reflection in a rational decision-making perspective,

- combining different dimensions of local development into a cohesive vision of the future,

- focusing on the mechanisms that connect different local processes that decide about the development of a municipality,

- identifying the actors of the local development,

- combining predictive perspective with anticipatory perspective (Klasik 1993).

\section{METHODOLOGY}

In the research project "Models of the economy development in municipalities in Natura 2000", we carried out much methodological and analytical work that aimed at:

- drawing up a typology of municipalities with Natura 2000,

- diagnosing local policies used for managing the development of Natura 2000 areas in relation to the type of municipality,

- determining evolutionary development scenarios taking into account the identified types and basic economic activities carried out in relation to Natura 2000 ,

- creating models of economic activities based on the results of the scenario analysis.

- The typology of municipalities with Natura 2000 has been developed primarily on the basis of statistical data. The basic data collection periods involve the years 2003, 2006 and 2009. The selection of the municipalities was determined by the following assumptions:

- coverage of the survey in all regions where there are municipalities with significant percentage of Natura 2000;

- to take into account diversity when choosing these municipalities, but always with a significant percentage of area covered by Natura 2000;

\footnotetext{
${ }^{1}$ Scientific work funded by National Science Centre in 2011-2013 as a research project "Models of economic activity in municipalities located in Natura 2000 protected areas" (N N305 173640).
} 
- to take account those municipalities that may establish partnerships within the framework of the sustainable development policy pursued.

An important goal was to identify the types of municipalities with Natura 2000 based on the concept of sustainable development. In our research practice, this meant that:

- for the determination of types of municipalities with Natura 2000 we used a pair of criteria, one of which was the high proportion of Natura 2000 and the second was economic criterion - socio-cultural, spatial and infrastructure;

- the main objective of the creation of a typology was to provide an indication of the types of Natura 2000 with regard to the concept of sustainable development on the basis of the observations of the situation occurring in the population; in other words, the aim of the study was to offer an indication of the types corresponding to the Polish municipalities, rather than creating a comprehensive typology of speculative nature - the survey indicated the municipalities that are the most vivid illustrations of the given type.

As a result of the application of this procedure, we have selected for further study 94 municipalities representing 15 regions and 15 counties. The collected data have enabled the assessment of the nature potential of municipalities, the demographic structure of municipalities, civil engagement of local communities, local economy, budget importance of natural resources, expenditure budgets of municipalities for the purposes related to the protection of the environment, expenditure budgets of municipalities and activities oriented towards the implementation of sustainable development, the availability of social infrastructure in the communities surveyed, infrastructure of municipalities, tourist infrastructure in the surveyed municipalities, the economy and the labour market, as well as spatial planning. Based on surveys, we have established five criteria for the determination of types of municipalities: the strength of the local economy, the level of use of environmental resources, demography, social capital, and environmental protection and spatial policy.

For each of the selected criteria, two municipalities were chosen (located on basis of the extreme positions according to the selected criteria). Then, for those municipalities we conducted in-depth research, in particular including a survey and examination of local planning documents. The survey conducted in the chosen municipalities focused on:

- evaluation of the natural potential of the municipality,

- circumstances of changes and processes in areas of great natural value,

- natural features of quality of life in the municipality,

- local activity for the benefit of sustainable development,

- competence of the local government in the field of action for sustainable development,

- cooperation of local stakeholders for sustainable development. The next phase of the research was to develop scenarios for the development of Natura 2000 areas; the focus was on evolutionary scenarios, but we have adopted a series of guidelines for profiling the scenarios. Among these may be mentioned:

- the development of industry-specific scenarios, taking into account the relationship between the development of industries and Natura 2000;

- the development of scenarios according to the types of designated municipalities based on an analysis of socio-demographic, economic and environmental factors; five types of designated municipalities were adopted on the basis of: (1) strength of the local economy, (2) use of environmental resources, (3) demographic potential, (4) social capital and (5) environmental protection and spatial policy;
- for each type, extreme scenarios have been developed for 'leading' municipalities and 'problematic' municipalities in the framework of a specific criterion; determination of types of municipalities has been supported by tests on the population of Polish municipalities with the highest percentage of Natura 2000 areas;

- development of two types of scenarios: the synergy scenario, which is a shared development of industries and conscious use of Natura 2000 values, and scenario of parallel or conflicting development, which is the development of the industries without a conscious reference to the values of Natura 2000.

Scenarios have been supplemented by the identification of the transaction costs. These costs are defined as the total costs of the functioning of the socio-economic system covering the expenditure of resources in the course of concluding and executing of all types of transactions (Stankiewicz 2007).

\section{SCENARIOS OF DEVELOPMENT IN MUNICIPALITIES WITH NATURA 2000 AREAS}

As a result of the study, we have prepared scenarios and models of development for municipalities with Natura 2000 areas. The work has been carried out in accordance with the previously described methodological assumptions. Because of the wide range of scenarios and models, Table 1 below shows only one scenario related to development of agriculture, forestry and fishing in the municipalities located in Natura 2000 protected areas.

The included scenario is very synthetic and focuses on a few main aspects and processes. Elaborating scenarios that could be a basis for formulating development strategies for particular municipalities with Natura 2000 areas would require a more detailed scenario and also, more than anything, wide public consultations. The included example, however, can be an illustration of a model process of generating a system of sustainable development scenarios for the municipalities located in Natura 2000 protected areas.

Elaboration of a model based on the development scenarios of Natura 2000 areas was preceded by the determination of the development process structure with the selected economic activities (Fig. 1). A demanded scheme for transformation of industries with relation to natural values is based on the analysis of the gathered data.

\section{SUMMARY}

The essence of the use of scenario methods in territorial units is versatile and dynamic analysis of development processes. The development of scenarios involves investigating the relationships between different local actors, the relationships between phenomena and identifying the conditions that are critical for strategic development. Multivariate evolutionary scenarios show how the different effects of the development can be based on local policy. In the case of the municipalities of the Natura 2000, key factors with decisive influence on the development are local natural values and the ability to use them in accordance with the principles of sustainable development.

The latter is related mainly to the experience, skills and creativity of local players. Scenarios always depend on the attitudes that are characteristic of the local communities. Negative attitudes leading to the implementation of conflict scenarios instead of synergistic are, for example:

- ignoring natural values and attempts to implement socio-economic development without respect for these values, 
Table 1. Scenarios related to the development of agriculture, forestry, hunting and fishing - scenarios for municipalities with extreme pace of economic development (sector A)

\begin{tabular}{|c|c|c|c|c|}
\hline \multirow{2}{*}{$\begin{array}{l}\text { Phenomena } \\
\text { and effects }\end{array}$} & \multicolumn{2}{|c|}{ Scenario of synergy } & \multicolumn{2}{|c|}{ Scenario of parallel or conflictive } \\
\hline & leading municipalities & problem municipalities & leading municipalities & problem municipalities \\
\hline $\begin{array}{l}\text { Phenomena that create } \\
\text { a scenario }\end{array}$ & $\begin{array}{l}\text { - investing in functions } \\
\text { considered commer- } \\
\text { cially prospective } \\
\text { - connecting develop- } \\
\text { ment of sector A with } \\
\text { science and research } \\
\text { - better adjustment of } \\
\text { products to market } \\
\text { needs } \\
\text { - ecological priority in } \\
\text { development of func- } \\
\text { tions } \\
\text { - developing activities } \\
\text { related to sector A, } \\
\text { including tourism and } \\
\text { agrotourism, which } \\
\text { make use of the val- } \\
\text { ues of Natura } 2000 \\
\text { areas } \\
\text { - development of com- } \\
\text { panies of agricultural } \\
\text { and food processing } \\
\text { that supports devel- } \\
\text { opment of sector A } \\
\text { - high fiscal potential } \\
\text { of municipalities that } \\
\text { allows to implement } \\
\text { local policy of sup- } \\
\text { porting development } \\
\text { of sector A }\end{array}$ & $\begin{array}{l}\text { - limited possibilities of } \\
\text { investing in develop- } \\
\text { ment of sectors } \\
\text { - sustaining activity } \\
\text { in sector A by public } \\
\text { entities, especially in } \\
\text { forestry } \\
\text { - undertaking by a part } \\
\text { of farms pro-ecolog- } \\
\text { ical actions oriented } \\
\text { to transform profile of } \\
\text { production } \\
\text { - attempts to develop } \\
\text { associated activities, } \\
\text { including tourism, } \\
\text { which make use of } \\
\text { values of Natura } \\
2000 \text { areas } \\
\text { - weak fiscal potential } \\
\text { that makes imple- } \\
\text { mentation of local } \\
\text { economic policy dif- } \\
\text { ficult }\end{array}$ & $\begin{array}{l}\text { - preferences for } \\
\text { quantitive develop- } \\
\text { ment and commodity } \\
\text { economy } \\
\text { - investing in functions } \\
\text { that are considered } \\
\text { commercially profit- } \\
\text { able and that do not } \\
\text { necessarily respect } \\
\text { natural values } \\
\text { - mechanisation of } \\
\text { production in sector A } \\
\text { - development of com- } \\
\text { panies of agricultural } \\
\text { and food processing, } \\
\text { which supports devel- } \\
\text { opment of sector A } \\
\text { - high fiscal potential } \\
\text { of municipalities that } \\
\text { makes implementa- } \\
\text { tion of local policy of } \\
\text { supporting develop- } \\
\text { ment of sector A } \\
\text { possible }\end{array}$ & $\begin{array}{l}\text { - decline of little farms } \\
\text { - imited possibilities of } \\
\text { investing in develop- } \\
\text { ment of entities in } \\
\text { sector A } \\
\text { - sustaining activity } \\
\text { in sector A by public } \\
\text { entities, especially in } \\
\text { forestry } \\
\text { - attempts to develop } \\
\text { activities that are } \\
\text { complementary to } \\
\text { activity of sector A } \\
\text { - weak fiscal potential } \\
\text { that makes imple- } \\
\text { mentation of local } \\
\text { economic policy dif- } \\
\text { ficult }\end{array}$ \\
\hline $\begin{array}{l}\text { Local effects of imple- } \\
\text { menting a scenario }\end{array}$ & $\begin{array}{l}\text { - fixation of economic } \\
\text { structure of munici- } \\
\text { pality } \\
\text { - strengthening of } \\
\text { strong specialisations } \\
\text { and produce of the } \\
\text { municipality } \\
\text { - } \text { fixation of workplaces } \\
\text { and stabilisation of } \\
\text { job market in sector A } \\
\text { - emergence of new } \\
\text { companies and work- } \\
\text { places in associated } \\
\text { sectors }\end{array}$ & $\begin{array}{l}\text { - limited implemen- } \\
\text { tation of policy of } \\
\text { supporting sector } \\
\text { development related } \\
\text { to low level of budget } \\
\text { revenue } \\
\text { - stagnation in devel- } \\
\text { opment of sector } \\
\text { A resulting from } \\
\text { fewer opportunities } \\
\text { to implement innova- } \\
\text { tive solutions } \\
\text { - low added value of } \\
\text { products resulting } \\
\text { from poorly devel- } \\
\text { oped processing } \\
\text { industry }\end{array}$ & $\begin{array}{l}\text { - fixation of economic } \\
\text { structure of mu- } \\
\text { nicipality without } \\
\text { important qualitative } \\
\text { changes } \\
\text { - increased efficiency } \\
\text { of entities in sector A } \\
\text { - possible reduction of } \\
\text { workplaces because } \\
\text { of priority of efficiency } \\
\text { - transfer of negative } \\
\text { effects of using tech- } \\
\text { nology in sector A on } \\
\text { natural environment } \\
\text { - emergence of new } \\
\text { companies and new } \\
\text { workplaces in associ- } \\
\text { ated sectors }\end{array}$ & $\begin{array}{l}\text { - } \text { reduced number of } \\
\text { active farms } \\
\text { - stagnation in devel- } \\
\text { opment of sector } \\
\text { A resulting from } \\
\text { fewer opportunities to } \\
\text { implement innovative } \\
\text { solutions } \\
\text { - economic regress of } \\
\text { municipality } \\
\text { - limited implemen- } \\
\text { tation of policy of } \\
\text { supporting sector } \\
\text { development related } \\
\text { to low level of budget } \\
\text { revenue } \\
\text { - low added value of } \\
\text { products resulting } \\
\text { from poorly devel- } \\
\text { oped processing } \\
\text { industry }\end{array}$ \\
\hline
\end{tabular}

Source: own elaboration

- excessive focus on the natural values and neglecting thinking about meeting the daily needs of local communities,

- treatment, a priori, of the Natura 2000 as a barrier preventing the implementation of innovative local development trends.

Therefore, involvement of a broad spectrum of local actors in a scenario development partnership should be recommended. This solution will provide not only an exchange of views between the parties, but will also contribute to changing and enriching the perception of Natura 2000 sites and their role in the development of communities. Scenario approach, although relatively new in the matter of resolving conflicts in communities of Natura 2000 sites, can be considered as promising and useful. Applying this approach fits in the lively discussion in the country on the relationship between local development and the protection of Natura 2000 sites. Development scenarios based on a strategic and holistic approach to the description and prediction of reality can fill the gap of tools required for decision-making by local governments. In particular, the results of applying the scenario approach enable the identification of risks in decision-making process, and allow paying attention to potential areas of conflict. 


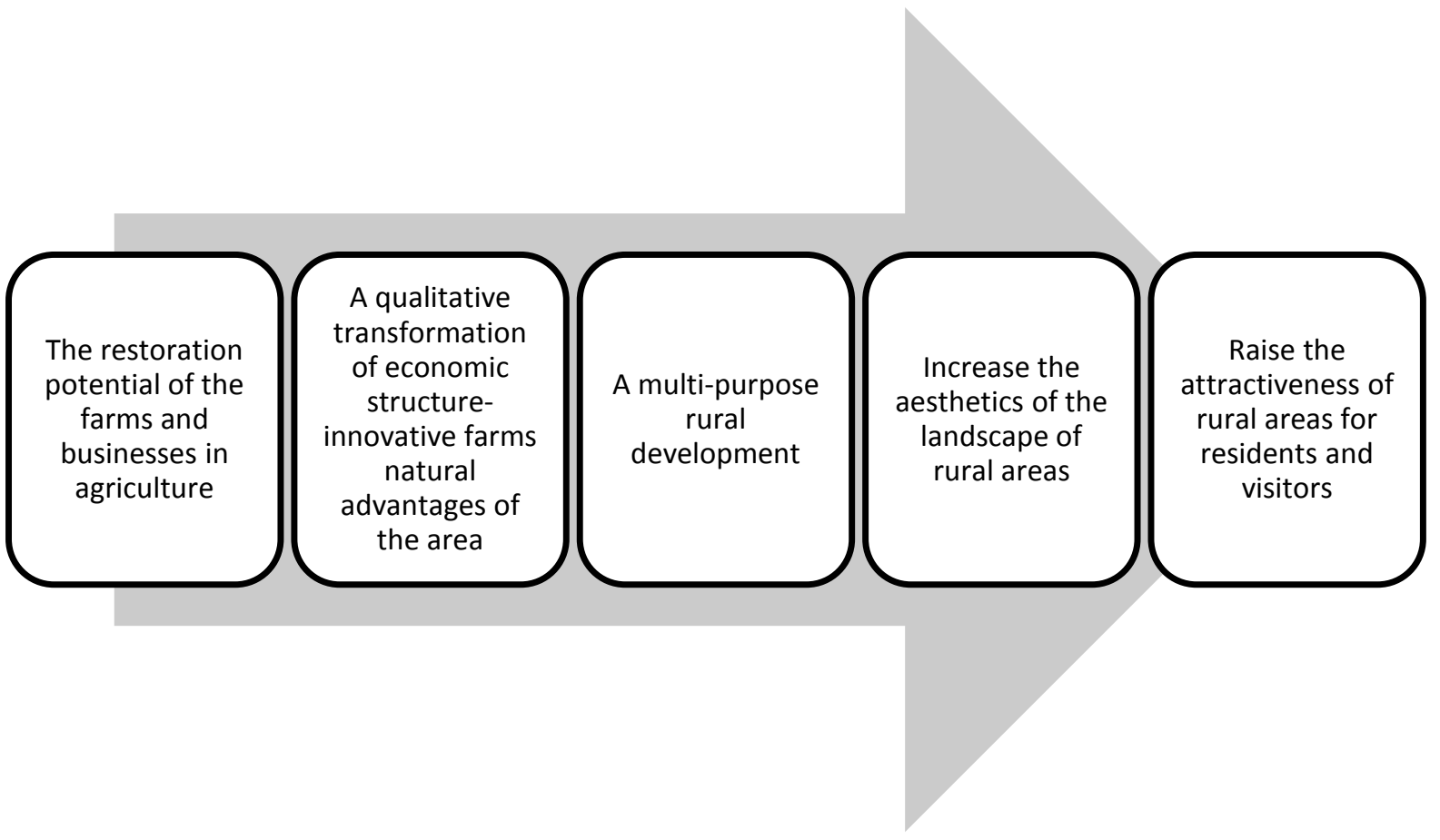

Fig. 1. The structure of the economic activities development process in the municipalities with Natura 2000 areas - agriculture, forestry, hunting and fisheries

\section{REFERENCES}

BROWN K. 2002. Innovations for conservation and development, The Geographical Journal, Volume 168, Issue 1: 6-17.

CAMAGNI R. 1992. Development Scenarios and Policy Guidelines for the Lagging Regions in the 1990s, Regional Studies Volume 26, Issue 4: 361-374.

GAUSEMEIER J., FINK A., SCHLAKE O. 1998. Scenario Management: An Approach to Develop Future Potential, Technological Forecasting and Social Change, Volume 59, Issue 2: 111-130.

GRZEGORZEWSKA E., RUNOWSKI H. 2008. Zdolności prognostyczne polskich modeli dyskryminacyjnych w badaniu kondycji finansowej przedsiębiorstw rolniczych, Rocz. Nauk Rol., Seria G, t. 95, z. 3-4: 83-90.

KLASIKA. (red.). 1993. Planowanie strategiczne, PWE, Warszawa. KOK K., PATEL M., ROTHMAN D.S., QUARANTA G. 2006. Multi-scale narratives from an IA perspective: Part II. Participatory local scenario development, Futures, Volume 38, Issue 3: 285-311.
Modele działalności gospodarczej w gminach położonych na obszarach Natura 2000 [Models of Economic Activity in Municipalitys Located in Natura 2000 Protected Areas] , research project NN305 173640 carried out in IOŚ PIB. 2013.

PALANG H., ALUMËE H., MANDER Ü. 2000. Holistic aspects in landscape development: a scenario approach, Landscape and Urban Planning, Volume 50, Issues 1-3: 85-94.

ETIENNE M., LE PAGE C., COHEN M. 2003. A Step-by-step Approach to Building Land Management Scenarios Based on Multiple Viewpoints on Multi-agent System Simulations. Journal of Artificial Societies and Social Simulation, Volume 6, no. 2.

STREET P., 1997. Scenario workshops: A participatory approach to sustainable urban living? Futures. Volume 29, Issue 2: 139-158.

STANKIEWICZ W. 2007. Ekonomia instytucjonalna - zarys wykładu, Wydawnictwo Prywatnej Wyższej Szkoły Businessu, Administracji i Nauk Komputerowych, Warszawa. 